M A K I N G MOROS 



\section{MAKING MOROS}

Imperial Historicism and American Military Rule in the Philippines' Muslim South

MICHAEL C. HAWKINS

NIU PRESS / DeKalb, IL 
(C) 2013 by Northern Illinois University Press

Published by the Northern Illinois University Press

in conjunction with the Center for Southeast Asian Studies,

DeKalb, Illinois 60115

All Rights Reserved

Design by Shaun Allshouse

Library of Congress Cataloging-in-Publication Data

Hawkins, Michael (Michael C.), author.

Making Moros : imperial historicism and American military rule in the Philippines Muslim South / Michael C. Hawkins.

pages $\mathrm{cm}$

"Published by the Northern Illinois University Press in conjunction with the Center for Southeast Asian Studies, DeKalb, Illinois"-Title page verso.

Includes bibliographical references and index.

Summary: "This book offers a unique look at the colonial creation of Muslim subjects during the early years of American rule in the southern Philippines. It examines the Islamic Philippines during its most formative period in modernity-a period indispensible to discussions of integration in the Filipino Islamic South" - Provided by publisher.

ISBN 9780875804590 (cloth) - ISBN 9781609090746 (e book)

1. Muslims-Philippines-Mindanao Island-History. 2. Muslims-Philippines-Sulu Archipelago-History. 3. Military occupation-Social aspectsPhilippines-Mindanao Island-History. 4. Military occupation-Social aspects-Philippines-Sulu Archipelago-History. 5. Mindanao Island (Philippines)-History. 6. Sulu Archipelago (Philippines)-History. 7. PhilippinesHistory-1898-1946. 8. Philippines-Relations-United States. 9. United States-Relations-Philippines. 10. Imperialism-History. I. Title.

DS666.M8H39 2013

959.9'7032-dc23 